\title{
Spatio-temporal Variations in the Physiological Profiles of Streambed Bacterial Communities: Implication of Wastewater Treatment Plant Effluents
}

Philips 0 Akinwole ( $\square$ poakinwole@crimson.ua.edu )

DePauw University https://orcid.org/0000-0002-4025-9338

\section{Amerti Guta}

DePauw University

Madeline Draper

DePauw University

\section{Sophia Atkinson}

DePauw University

\section{Research Article}

Keywords: CLPP, microbial biomass, bacterial community structure, wastewater effluents, metabolic profile, seasonal variations

Posted Date: February 22nd, 2021

DOl: https://doi.org/10.21203/rs.3.rs-235501/v1

License: (c) (i) This work is licensed under a Creative Commons Attribution 4.0 International License. Read Full License

Version of Record: A version of this preprint was published at World Journal of Microbiology and Biotechnology on July 17 th, 2021. See the published version at https://doi.org/10.1007/s11274-02103106-2. 


\section{Abstract}

The effluents of wastewater treatment plants (WWTPs) represent a complex mixture of nutrients and toxic substances, thus, the potential exists for the effluents to significantly impact the biochemical characteristics and bacterial communities of the receiving water. We examined spatial and seasonal patterns, and the impact of effluents on microbial biomass, bacterial community structure, and metabolic diversity on a fourth-order stream. We took triplicate sediment samples at five different locations along a $5,000 \mathrm{~m}$ transect over three sampling periods. We quantified bacterial community structure as communitylevel physiological profiles and biomass with phospholipid phosphate analysis. Our findings highlight the worrisome impacts of effluents on microbial biomass and bacterial metabolic diversity on the receiving water. Microbial biomass was significantly higher at the WWTP outfall compared to upstream and downstream sites and correlated positively with sediment physicochemical parameters. Furthermore, our data revealed significant spatial differences in bacterial community structure in the context of WWTP impact. High nutrient availability (lower carbon/nitrogen ratios) at the outfall increased site-specific bacterial metabolic diversity in winter but decreased the same in fall. Seasonal changes in the sedimentary microbial biomass and bacterial carbon substrate utilization were evident regardless of the spatial variations or impacts of the wastewater effluents. Communities in fall showed more versatile substrate utilization patterns than the winter communities. These results suggest that WWTP effluents significantly increased microbial biomass and highlight its mixed effects on bacterial community structure and metabolic diversity. Also, our data underscore a close association between sedimentary physicochemical parameters and the associated microbial functional activities.

\section{Introduction}

Anthropogenic disturbances such as wastewater treatment plant effluents, irrigation with treated wastewater, heavy metals pollution, agricultural uses of antibiotics, pesticides, and fertilizers have considerable impacts on the biotic properties of natural aquatic ecosystems, especially microbial activity and processes (Englert et al. 2013; Kunhikrishnan et al. 2017), biomass (Wang et al. 2007a), and community structure (Dang et al. 2019; Guo et al. 2019). Wastewater treatment plant (WWTP) effluents are considered as one of the major sources of nutrient and micropollutants (Bueno et al. 2012) for aquatic ecosystems, for instance, effluents introduce large amounts of ammonia to the environment, and ammonia-oxidizing bacteria was shown to be able to escape the WWTP and grow far downstream in an aquatic environment (Cebron et al. 2004). Moreover, WWTP effluents have been shown to moderate microbial metabolic profiles and biomass downstream of their effluents (Lu and Lu 2014; Tao et al. 2017; Tiquia 2010; Wang et al. 2017), and the amount of effluents released into an aquatic environment can also impact biodiversity; low amounts of WWTP effluents increased biomass, but deceased biodiversity while high amounts of WWTP effluents increased biodiversity but decreased overall biomass (Tao et al. 2017).

In most developed countries, progress in WWTP processes removes the majority of solid organic matter as well as nitrogen and phosphorus, however, biochemical parameters of effluents are in stark differences 
to that of the water in the receiving lotic system. Moreover, chemicals of emerging concern such as human steroid hormones, pharmaceuticals (e.g. antibiotics and antidepressants), and personal care products that WWTPs were not designed originally to remove, are washed down sink drains and enter municipal wastewater systems and have been detected in surface waters around the world (Khan et al. 2019; Sabri et al. 2020). Spatial variations in microbial biomass and functions are thus expected in sediments downstream of the WWTP effluents compared to unaffected natural sediments upstream (Drury et al. 2013). In fact, Wakelin et al. (2008) reported the effect of the WWTP effluents on microbiological characteristics for more than $1 \mathrm{~km}$ downstream.

Microbiota in the temperate biome are exposed to stark seasonal changes in their physicochemical environments, thus, it is not unexpected that microbial community structure might also vary between seasons. Previous studies have demonstrated seasonal variation in the streambed microbial community and functions, and these variations are commonly attributed to key drivers of ecosystem change, such as moisture content, temperature, dissolved oxygen, and organic nutrient content (Autio 1998; Olapade and Leff 2004; Hullar et al. 2006; Zeglin 2015). Other variables such as storm frequencies, cation/anion concentrations, quantity, and quality of allochthonous and autochthonous inputs that directly influence stream microbial communities have not been well circumscribed (Gremm and Kaplan 1998; Sabater et al. 2000; Mosher and Findlay 2011). Also, much is still unknown about the relative importance of seasonality and spatial heterogeneity in predicting microbial community structures that are impacted by anthropogenic perturbations.

The fast response and sensitivity of microbial biomass, community structure, and metabolic activity to perturbations contribute to the fact that microbial parameters are useful indicators for the assessment of ecosystem integrity (Schloter et al. 2003). Several studies have been conducted on stream microbial communities using molecular tools (Araya et al. 2003; Böckelmann et al. 2000; Manz et al. 1998), however, studies on bacterial metabolic diversity and their link to effluents are few. For instance, Harbott and Grace (2005), reported increased importance of peptides as a carbon source for heterotrophic bacteria in urban streams compared to a more diverse range of carbon sources in less-urbanized streams. In another study, Tiquia (2010), showed that river heterotrophic microbial populations utilized carbohydrates, polymers, and phenolic compounds more frequently in the spring, and carboxylic acids and amino acids in the summer. One approach to monitoring changes in the microbial communities and metabolic diversity is by physiological profiling with EcoPlate ${ }^{\mathrm{Tm}}$ (Biolog, Inc.), which is designed for the investigation of environmental samples. This is a quick and sensitive assay to characterize the metabolism of bacterial communities, referred to as the Community-Level Physiological Profile (CLPP), and has been used to detect changes in microbial community physiological structures over time or between different habitats (Nájera et al. 2020; Jałowiecki et al. 2016; Tiquia 2010).

In this study, we investigated microbial biomass measured by phospholipid phosphate, community structure, and carbon substrate utilization patterns of the sedimentary bacterial communities, along the Big Walnut Creek in Greencastle, IN. Our main goals were (i) to determine the potential of CLPP assay for resolving the metabolic diversity of the stream sediments on temporal and spatial scales, and (ii) to 
elucidate a close linkage between the sedimentary physicochemical properties and the associated microbial metabolic diversity and functional activities. Five sites along the Big Walnut Creek were sampled to reflect spatial differences in the context of WWTP impacts. These sites were sampled during the fall (September and October) of 2019 and winter (February) of 2020 to reflect seasonal differences. Our data demonstrated significant seasonal changes in the sedimentary microbial biomass and bacterial community structure regardless of exhibited spatial variations associated with the impact of WWTP effluents.

\section{Materials And Methods}

\section{Site description and sediment sampling}

Big Walnut Creek (BWC), a tributary of the Eel River flows through the town of Greencastle, approximately $90 \mathrm{~km}$ west of Indianapolis, IN (USA), and receives tertiary-treated level (UV system) effluents from the Greencastle municipal WWTP. The WWTP services a population of approximately 11,000 people from the towns of Greencastle and Fillmore, Indiana. The creek is a 4th order stream that drains most of Putnam County. BWC flows through an area largely cleared of native vegetation and used mainly for agriculture (Fig.1). The riparian vegetation is limited to a fringe of trees and shrubs along the banks. Approximately $30 \%$ of the banks along BWC were exposed to moderate to severe erosion (Gammon 1994) and adjacent lands are periodically flooded. The monthly mean discharge ranged from 425.4 to $0.36 \mathrm{~m}^{3} / \mathrm{s}$ for 2019 , and the base streamflow is highly variable between seasons. In addition, BWC is muddy when it rains. Of cultural and historic significance are the several covered bridges (e.g. Dunbar Covered bridge, Oakalla Covered bridge, Houck Covered bridge, and Huffman Covered bridge) which cross the stream at different locations.

Sediment samples were collected each on September 3, and October 29, 2019, and February 262020 at five stations along a 5,000 m-transect of the BWC. Triplicate sediment samples were collected at two locations upstream of the WWTP outfall, one at the WWTP outfall, and two locations downstream of the WWTP outfall, as described below. Samples were collected (1) at Dunbar Covered Bridge (DCB) flanked at a side by corn-soybean rotation field, which was located approximately $1660 \mathrm{~m}$ upstream of the outfall (inferred as an undisturbed reference site with respect to the outfall), (2) location approximately 50m upstream of the outfall was referred to as WWU, (3) location at the WWTP outlet pipe i.e. near the meeting of the WWTP effluents and the BWC referred to as WWD, the effluents runs over large cobbles and rocks that extends back towards WWU, (4) location about 1420m downstream of WWD at DePauw University Nature Park (NP) where the stream flows through a small size fragmented eastern deciduous forest in the park, and (5) location approximately $3340 \mathrm{~m}$ downstream of the WWD at Oakalla Covered Bridge (OCB) with adjacent lands as agricultural fields (Fig. 1). During the October sampling, we observed increased inputs of allochthonous materials (falling leaves, twigs and algae streamers) along the sampling transect. 
At each location, triplicate sediment composite samples were collected with a hand-held sterile $(0.15 \mathrm{~m}$ by $0.07 \mathrm{~m}$ ) stainless spoon sampler and lifted from the stream with minimal disturbance. Every single composite sample consists of multiple sediment cores. Sediments in the top $2 \mathrm{~mm}$ that were not washed down were transferred with a sterile spatula to pre-labeled Whirl-Pak sampling bags and stored on ice until delivery to the laboratory. Within four hours of sampling, sediments were transferred to a clean plastic weigh boat, thoroughly homogenized, subsampled for microbial biomass, community-level physiological profile, percent water content, and elemental analyses.

\section{Physico-chemical parameters}

The percent moisture content of the sediment samples was determined by the difference in mass after oven drying at $110^{\circ} \mathrm{C}$ to constant mass. Water temperature and $\mathrm{pH}$ were taken directly in the field with a Direct Soil Measurement pH Portable Meter (HANNA Instruments, USA). Samples for the total percent carbon and nitrogen contents' determination by direct combustion were sent to the Center for Applied Isotope Studies, University of Georgia, USA, for analysis.

\section{Total microbial biomass analysis}

Microbial biomass was determined using phospholipid phosphate (PLP) analysis as described in Akinwole et al. (2021). Briefly, frozen sediment subsamples (approximately $7 \mathrm{~g}$ ) were extracted in the dark at $4^{\circ} \mathrm{C}$ in $50-\mathrm{ml}$ screw-cap tubes with $27 \mathrm{ml}$ of a 1:2:0.6 ( $\left./ \mathrm{v} / \mathrm{v}\right)$ dichloromethane-methanol-50 mM phosphate buffer $(\mathrm{pH}$ 7.4) solution. The solution was partitioned into organic and aqueous phases with $7.5 \mathrm{~mL}$ dichloromethane and $7.5 \mathrm{~mL}$ deionized water, the organic phase (containing total lipid) was collected across a pre-dried 2V filter (Whatman, Thomas Scientific) into 15-ml test tubes, and the solvents dried under a stream of nitrogen at $37^{\circ} \mathrm{C}$. After lipid extraction, sediment was collected in the filter, dried at $100^{\circ} \mathrm{C}$, and weighed. Total microbial biomass was determined as total PLP (Findlay et al. 1989). Total lipid was dissolved in $2 \mathrm{ml}$ chloroform, and two replicate 100 -ul portions per sample were each oxidized with potassium persulfate at $100^{\circ} \mathrm{C}$ overnight in sealed glass ampoules to release orthophosphate. Phosphate was reacted with ammonium molybdate and malachite green, and the phosphomolybdatemalachite green complex was detected spectrophotometrically $(610 \mathrm{~nm})$. Concentrations of phosphate were calculated by using the regression line from a standard curve prepared by digesting glycerol phosphate.

\section{Community-level physiological profiling (CLPP)}

CLPP based on sole-carbon substrate utilization (Garland and Mills 1991; Preston-Mafham et al. 2002) was performed using 96-well Biolog ${ }^{\circledR}$ EcoPlates (Biolog Inc., Hayward, CA). The EcoPlate has three replicated wells of 31 of the most useful carbon sources for soil community analysis, including amino acids, amines/amides, carbohydrates, carboxylic acids, and polymers. We mixed and agitated homogenized $2 \mathrm{~g}$ of soil in $18 \mathrm{ml}$ of Remel ${ }^{\text {TM }}$ Butterfield's Phosphate Buffer. Then, the suspension was diluted at $10^{-3}$ and $150 \mu$ of this latter was inoculated to each well in the EcoPlate. Three wells contained sterilized water to serve as controls. EcoPlates were incubated under aerobic conditions at $27^{\circ} \mathrm{C}$ and 
Optical Density (OD) at $590 \mathrm{~nm}$ measured using a plate reader $\mu$ Quant (BIO-TEK Instruments, Inc) daily for 7 days. The metabolic activity of the sediment microbial community was calculated according to the average well color development (AWCD). It was defined as the arithmetic average of the absorbance values for each substrate (Harch et al. 1997),

$\mathrm{AWCD}=\Sigma(\mathrm{Ci}-\mathrm{R}) / \mathrm{n}$,

where $\mathrm{Ci}$ is the absorbance of the carbon-source,

$\mathrm{R}$ is the absorbance of the control well

and $\mathrm{n}$ is the number of carbon substrates (31 for EcoPlates).

When $\mathrm{Ci}-\mathrm{R}<0$, the values were set to 0 to minimize bias. AWCD indicates the total metabolic capacity of sediment microbial communities in terms of carbon-source utilization. The OD values for data evaluation and comparisons were used at $120 \mathrm{hr}$ since these represented the optimal range of OD readings in our study (Gryta et al. 2014; Nagy et al. 2013).

Shannon diversity index $(H)$ and Evenness $(E)$ were calculated using an OD of 0.25 as the threshold for a positive response. Shannon diversity index $(\mathrm{H})$ and Evenness $(\mathrm{E})$ are defined as $\mathrm{H}=-\Sigma \mathrm{Pi} \ln (\mathrm{Pi})$ and $\mathrm{E}=$ $\mathrm{H} / \mathrm{H}_{\max }=\mathrm{H} / \mathrm{In} \mathrm{S}$, respectively, where $\mathrm{Pi}=\mathrm{ODi} / \Sigma O D i$, which is the proportional color development of the well over total color development of all wells of a plate and $S$ is the number of oxidized C substrates (Muñiz et al. 2014; Garland and Mills 1991).

\section{Statistical analysis.}

Two-way analysis of variance (ANOVA) with sampling time (season) and the site as factors, followed by Tukey's highly significant difference (HSD) as a post hoc test for comparison of means was performed for H-index and total microbial biomass. Principal components analysis (PCA) (IBM SPSS Statistic, version 26) was used to determine differences between community-level physiological profiles across sites and seasons. PCA to analyze CLPPs was performed on normalized and log-transformed absorbance data for each well. Sediment samples from different seasons and sites were considered independent because samples were collected at least one-month intervals, never collected from exactly the same spot (see sample collection above), and supposed to reflect ambient conditions in time and space. Two-way ANOVA followed by Tukey's HSD as a post hoc test was used to analyze the effect of site and season on the major parameters determined for the BWC. Assessing the utilization profiles involves grouping the 31 carbon sources into 5 guilds according to Weber et al. (2009), and assessing changes in the percent guild utilizations over the study period. Essentially this method compresses the 31-dimensional space of anyone plate into 5 dimensions to facilitate simple plotting and interpretation. A heat map was generated and 3-way ANOVA with sampling time (season), guild, and the site as factors, followed by Tukey's HSD as a post hoc test for comparison of means was performed for carbon utilization profiles. Shannon diversity and evenness indexes were compared by two-way ANOVA. Best 
subsets regression analysis and analysis of variance (ANOVA) were performed using the StatPlus for Mac program (AnalystSoft Inc.). Tests of significance were considered statistically significant at $p$ values of $<0.05$ or $<0.01$.

\section{Results}

\section{Physico-chemical parameters}

Table 1 shows the measured microbial biomass, $\mathrm{H}$-index, and physicochemical parameters across the five sites studied for each sampling date. Temperature varied significantly with season $(F=9590.7, p<$ 0.001 ) and sampling sites $(\mathrm{F}=12.33, \mathrm{p}<0.001)$ (Table 2). Mean temperatures were $23.4^{\circ} \mathrm{C}, 12.9^{\circ} \mathrm{C}$, and $2.3^{\circ} \mathrm{C}$ in September and October 2019 and February 2020, respectively. In addition, post hoc comparison among sampling sites indicated that temperature was generally higher at WWTP outfall (WWD) compared to other sites with the exception of September samples (Table 1). pH did not show significant variations seasonally or by sites (data not shown). Percent moisture content varied from $21.30 \%$ (in February 2020) to $69.84 \%$ (October 2019) with significant seasonal difference ( $F=7.95, p<0.05)$ (Table 1). Tukey HSD further revealed significant differences between WWD vs NP and OCB, and DCB vs NP and OCB $(\mathrm{p}<0.05)$. $\mathrm{C} / \mathrm{N}$ ratios were measured to determine if nutrient concentrations in downstream water were more similar to the WWTP outfall or upstream water. $\mathrm{C} / \mathrm{N}$ ratio was significantly different seasonally $(F=24.25, p<0.001)$ and spatially $(F=3.56, p<0.031) . C / N$ ratios were generally lower at the WWD site, and the further away from the outfall, the higher the $\mathrm{C} / \mathrm{N}$ ratios measured in February 2020 and September 2019, with the exception of OCB (Table 1 and 2). Both percent Nitrogen and Carbon contents were significantly different seasonally and spatially and showed significant interactions between seasons and sites (Table 2). Overall, mean values of both percent Nitrogen and percent Carbon contents followed a general order of February 2020 < September 2019 < October 2019. Post hoc comparison among sampling sites indicated that in general both percent Nitrogen and Carbon contents were higher at WWD compared to DCB, NP, and OCB sites (Table 1).

\section{Total microbial biomass and physico-chemical parameters}

Total microbial biomass, measured as total phospholipid phosphate, ranged from 1.3 (in February 2020) to 113.6 (October 2019) nmol PLP g ${ }^{-1}$ dry wt sediment (Fig. 2). Total microbial biomass showed significant seasonal difference $(p<0.001)$ and longitudinal patterns along the BWC $(p<0.001)($ Table 2$)$. The results of the two-way ANOVA (Table 2) demonstrate significant effects of site and sampling date on microbial biomass. Microbial biomasses were significantly lower during the winter season (Fig. 2) and coincided with the lowest water temperatures and percent moisture content (Table 1). Microbial biomasses were higher in the late fall/October 2019 (Fig. 2) and coincided with the warm temperature, higher percent moisture content, and allochthonous inputs. Also, microbial biomass was significantly greater at the WWD site, and the further away from the outfall, the lower the biomass measured. Temperature, percent Nitrogen content, percent Carbon content, and $\mathrm{C} / \mathrm{N}$ ratio were used as predictor variables to analyze relationships between natural log-transformed $(\ln +1)$ microbial biomass and these 
physicochemical parameters. In Table 3, the best subset regression analysis indicated that total percent Nitrogen content provided the best single variable model explaining the variation in total sedimentary microbial biomass (adjusted $r^{2}=0.66, p<0.001$ ). However, a combination of total percent Carbon content, percent Nitrogen content, $\mathrm{C} / \mathrm{N}$ ratio, and temperature (model 4) best explained the observed variation in the microbial biomass (adjusted $r^{2}=0.75, p<0.001$ ).

\section{Community-level physiological profiling (CLPP)}

PCA presented in Fig. 3 was done based on adjusted and log-transformed AWCD. PCA of the AWCD revealed a strong seasonal pattern in bacterial community structure in the BWC sediments. PC 1 accounted for $50 \%$ of the total variation and PC 2 explained another $10 \%$. According to PC 1, explaining the greater variance of the original data, samples from February (colder water temperatures) had zero to negative component scores (with the exceptions of OCB samples), while samples from September and October (warmer water temperature) had positive component scores. In order to further investigate spatial variability in bacterial community structure and exclude the effect of seasonality, PCA was conducted on bacterial physiological profiles during the period of cold water (edited to remove samples collected in warmer water) and during the period of warmer water (edited to remove samples collected in cold water) (Fig. 4). For the period of cold water, the samples formed three clusters (labeled I, II, and III) of bacterial community structure in the BWC sediments (Fig. 4a). Samples from NP formed one cluster and had negative PC 1 and PC2 component scores that were enriched in carbon substrates D-Glucosaminic acid, and $D$-Galactonic acid-y-lactone, these carbon substrates belong to the Carboxylic \& Acetic acids guild. Samples from DCB formed the second cluster and had positive PC2 component scores that were enriched in carbon substrate L-Asparagine (amino acid), Tween 40 (polymer), and D-Galactyronic acid (Carboxylic \& Acetic acids). The third cluster consists of samples from WWD, WWU, and OCB and had positive PC 1 component scores enriched in Glycogen (polymer), a-Cyclodextrin (polymer), LPhenylalanine (amino acid), Glucose-1-phosphate (Carbohydrate), Putrescine (Amines \& Amides), Phenylethylamine (Amines \& Amides) (see Table S1 for PCA component loadings). However, within the third cluster, distinct bacterial communities are discernable based on location, for example, samples from WWU are dissimilar from OCB. Figure $4 \mathrm{~b}$ showed the bacterial community structure for the period of warmer water and PC1 showed that bacterial community composition displayed no consistent longitudinal variation among sites within a sampling period. Rather for some sites, for instance, WWD, the three replicate sample cores showed nearly identical bacterial community structure (dashed squares. Fig. 4b), while for other sites (DCB in October, and OCB in September) the three replicate sample cores differed greatly in bacterial community structure (dashed sphere. Fig. 4b). Bacterial community composition from September samples was further separated from October samples along PC 2, as September samples had negative component scores while October samples had positive component scores. The results of the Best Subsets regression analysis showed that percent Nitrogen content explained approximately $40 \%$ (Table 3, Model 4) of the variation in total sedimentary bacterial community structure (PC1). Combined, temperature, sediment percent Carbon content, percent Nitrogen content, and $\mathrm{C} / \mathrm{N}$ ratio explained 
approximately $60 \%$ of the variation observed in bacterial community structure in the BWC sediments (Table 3, Model 4).

\section{Carbon source utilization}

Bacterial metabolism fingerprint refers to the ability of bacteria to utilize different carbon sources on Biolog Ecoplates. The heatmap analysis was used to intuitively show the pattern of different carbon substrate metabolism of bacterial communities appearing across sites per season (Fig. 5). The results of the heat map showed that the AWCD values were significantly higher in September and October compared to February indicating that the density and the activity of streambed bacteria were significantly higher during the period of warmer water than the period of cold water. Overall, carbohydrates and polymers were preferred carbon substrates utilized by the bacterial community in the fall (see Table S2 for PCA component loadings). Fig. 6 presents the percent of total carbon source utilization for each guild (see Table S3 for guild groupings) as a functional diversity in this study. In general, utilization patterns of the five guilds varied significantly across seasons $(F=113.25, p<0.0001)$ as shown in Fig. 5 , and among sites $(F=32.79, p<0.0001)$ and within guilds $(F=5.50, p<0.001)$ (Table 4$)$. The results of the three-way ANOVA (Table 4) indicated significant effects of season and site on bacterial carbon utilization but no significant effects of season and guild, site and guild, or the combination of season, site, and guild. Specifically, carbon substrates were least utilized by the bacterial community at the NP site compared to WWU and WWD sites in February (Fig 5, Table 4). Carbon substrates were equally utilized at WWD and OCB sites (Table 4). Generally, carbohydrates (range: 21 - 32\%) were utilized more than amino acids (range: $16-26 \%$ ) and amino acids were utilized more than polymers (range: $12-16 \%$ ) or amide and amines (range: 3 - 8\%). Also, carboxylic acid and acetic acid (range: $27-47 \%$ ) were utilized more than polymers (Fig. 6, Table 4).

\section{Shannon diversity index and evenness index}

The mean values of the diversity of the bacterial communities calculated as the Shannon diversity index $(\mathrm{H})$ ranged from $2.24-3.38$ (Table 1). Differences among seasons were significant as there was high diversity during the period of warmer water than during the period of cold water $(F=5.64, p<0.005)$. At the site level, differences in $\mathrm{H}$-index reached only marginal significance $(F=2.47, p<0.065)$ as the posthoc test further showed that NP is significantly different from WWD, WWU, and OCB $(p<0.05)$ in February. In the case of Evenness, there were no significant differences among seasons and across sites (data not shown).

\section{Discussion}

\section{Spatial and seasonal variations in microbial biomass}

The sedimentary microbial biomass and bacterial community structure of BWC exhibited spatial variations associated with positioning from the WWTP outfall and a temporal pattern associated with seasonal differences. Notably, the further away (upstream and downstream) from the outfall, the lower 
the biomass measured, and the higher the $\mathrm{C} / \mathrm{N}$ ratios except for the OCB site in October when increased inputs of allochthonous materials might have obscured the effects of the WWTP effluents. Singularly to this observation, Wakelin et al. (2008) reported that the microbial biomass was highest at the mostdownstream sampling location, however, eutrophication was recorded at that site. Thus, our results, that total microbial biomass correlated positively with both sediment organic nitrogen and carbon, and $\mathrm{C} / \mathrm{N}$ ratio suggests that the decreased $\mathrm{C} / \mathrm{N}$ ratio at the WWTP outfall (compared to the other sites) implies high mineral Nitrogen availability. This increase in the total amount of soluble nitrate-N at the outfall was matched by an increase in microbial biomass. These findings indicated that the wastewater effluents had significant impacts on microbial biomass and activities of microbial communities and that these impacts are mediated through changes in the quality of carbon substrate and increased mineral $\mathrm{N}$ availability. Magesan et al. (2000) reported the largest increase in microbial biomass when low $\mathrm{C} / \mathrm{N}$ ratio wastewater is applied to experimental soil. Our data supported other studies as well that demonstrated increases in microbial biomass and activity in systems receiving wastewater (Button et al. 2015; Ma et al. 2015). Moreover, Aristi et al. (2015), reported that WWTP effluents can act as a subsidy promoting biomass and microbial communities, which can use dissolved nutrients and organic matter.

It was very surprising that despite elevated levels of nutrients present at WWD, microbial biomass decreased over a short distance downstream of the effluent inputs. This may be a consequence of attenuation, not simply dilution capacity, as shown by an increased $\mathrm{C} / \mathrm{N}$ ratio at the NP site. For instance, studies have shown that a load of phosphate and ammonium often shows downstream attenuation (Elósegui et al. 1995; Von Schiller et al. 2008). Though it is likely that the ecological impacts of the WWTP discharge would be less pronounced downstream of the outfall over a short distance, the effect of the disturbance on the longer-term ecological function (such as litter decomposition) of the stream is not clear.

Our data revealed some of the key drivers controlling temporal variation in microbial biomass in the stream ecosystem. We observed an increase in biomass from September 2019 to October 2019 and a significant decline in February 2010 in synchronous declines with percent water content and temperature from September/October 2019 to February 2020, patterns that were likely linked to overall carbon and nitrogen flow through the stream ecosystems. The seasonal variations in microbial biomass at these sites appeared to be driven, at least in part, by total percent Carbon content, percent Nitrogen content, $\mathrm{C} / \mathrm{N}$ ratio, water temperature, and percent moisture content. These factors are recognized as important environmental constraints of sedimentary microbial biomass (Findlay et al. 2002, Wang et al. 2007b). For instance, high percent water content allows for nutrient and substrate transfer between sediments and provide a means by which microorganisms can move to more favorable locations, thus, playing an important role in structuring soil microbial communities (Treves et al. 2003). We observed approximately a 3-fold increase in microbial biomass in October 2019 compared to September 2019. In larger and urban streams, abundant sunlight from the limited riparian canopy, cooler water temperatures, increased allochthonous inputs and elevated nutrient concentrations can lead to high streambed microbial biomass and activity as we observed in fall (Benfield 1997; Suberkropp 1997; Artigas et al. 2009; Tank et al. 2010). The differential sensitivity of microbial biomass to allochthonous input implies that microbial metabolic 
processing in streams will vary dramatically over time if the abundance of allochthonous inputs is highly variable. This has important implications for watershed management since any anthropogenic activity that accelerates the delivery of terrestrial dissolved organic matter into headwater streams could have pronounced effects on microbial biomass and activities (Akinwole et al. 2021).

\section{Spatiotemporal variation and carbon utilization patterns in bacterial community structure}

Functional diversity understood as the utilization of carbon sources (in Biolog EcoPlates) in this study, showed distinct variations between bacterial communities in reference to the outfall samples. PCA analysis of studied sites showed three clusters of winter samples. Group one consisted of bacterial communities from NP (downstream of WWTP outfall) and displayed preferential metabolism for carboxylic and acetic acids while cluster two consisting of DCB samples (upstream of WWTP outfall) displayed preferential metabolism of carboxylic and acetic acids, amino acids, and polymer. This less functional diversity at NP and DCB correlates with low $\mathrm{H}$ - index value at NP and DCB (Table 1). The samples from the third cluster consisting of bacterial communities from WWU (above WWTP outfall), WWD, and OCB (3340 m downstream the WWTP outfall), were characterized by higher utilization of a wider range of carbon sources including polymer, amino acids, carbohydrate, and amines and amides with AWCD values significantly higher than the samples from other two sites. Moreover, the higher $\mathrm{H}-$ index values from the third cluster imply higher functional diversity at these sites. Similarities of both WWU and WWD sites might be as a result of the proximity of these sites due to hyporheic exchange and turbulent mixing (Battin et al. 2003) with respect to the presence of large cobbles at the WWD study site. Land use pattern may be an alternative proximate cause for the observed high diversity in bacterial community structure at OCB since this site is located within pasture/hay and cultivated cropland (Fig.1). The disturbance (i.e. impacts of effluents) caused to sediments at WWTP outfall may create conditions of greater habitat heterogeneity and increased nutrient load than elsewhere along the creek and allowed the development of greater metabolic diversity observed.

In contrast to winter samples, in fall we did not observe distinct spatial variations but rather sediments from WWD sites showed substantially greater similarity in bacterial community composition than sediments from other sites (Fig. 4b). Urakawa et al. (2013) demonstrated that the detected variability among the environmental samples was not due to technical errors or poor reproducibility of CLPP methods, but rather by the community-level heterogeneity in the analyzed microbial samples. Thus, our observation indicates that toxic substances (such as pharmaceuticals) might be present in WWTP effluents, and these may have inhibited bacterial diversity at WWD sites compared to other sites in the fall (Nega et al. 2019). This explains the complexity in predicting the overall effect of WWTP effluents on stream bacterial metabolic activities and diversity. For instance, in Aristi et al. (2015) study that examined whether WWTP effluents were a subsidy or stress for river ecosystem functioning reported that the effluents produced mixed effects (evidence of WWTP effluents acting as both a subsidy and as a stressor) at the biofilm scale and ecosystem-scale metabolism. However, we cannot neglect that stream ecosystems as dense networks can experience a broad suite of coupled physicochemical and ecological processes that strongly influence microbial community structure and ecosystem functioning (Battin et al. 
2016). The effects of WWTP effluents on microbial community structure have been observed in other studies (Wakelin et al. 2008; Nega et al. 2019; Drury et al. 2013) as well.

Seasonal changes in the sedimentary bacterial community structure were evident regardless of the spatial variations or anthropogenic disturbance (wastewater effluents). PCA revealed the seasonal pattern in BWC microbial community structure, and variations in the drivers of ecosystem change such as percent moisture content, temperature, and $\mathrm{C} / \mathrm{N}$ ratios supported the PCA findings. Our study extends other reported shorter-term and annual cycle studies of seasonal variations in microbial communities (Smoot and Findlay 2001; Brummer et al. 2002; Sekiguchi et al. 2002; Feris et al. 2003; Oest et al. 2018). In winter, which showed the lowest percent moisture content and water temperatures, the catabolic activities of the bacterial communities in sediments across all sites decreased. For example, Amine/Amide (Putrescine, Phenylethylamine) and Amino acids (L-Threonine, L-Phenylalanine) were preferentially utilized in the fall, but the degradation ability was weak in winter. Similar results were found by Oest et al. (2018) who reported a decreased use of amino acids and amines and continued slight use of carbohydrates by microbial communities in the winter. Overall, more substrates were utilized in fall than in winter, and polymers and carbohydrates were the most intensively used carbon substrate categories by the bacterial community in the fall sample (Fig. 5, Table S3). Our data further support studies in metabolic capabilities of sedimentary bacterial community and showed that carbohydrates and or polymers are the preferred catabolic pathway and oxidation of many heterotrophic bacteria (Rosenstock and Simon 2003; Tiquia et al. 2008; Oest et al. 2018).

Taken together, our data suggest that there are significant spatiotemporal variations in microbial functions and carbon utilization patterns that appear to be linked to observed variations in abiotic and anthropogenic factors. However, future efforts should include detailed information on spatial and seasonal changes in the abundance of specific microbial taxa, so that we can begin to understand the metabolism of these groups and how they are linked to the larger ecosystem level.

\section{Conclusions}

In the present study, we investigated the spatial and temporal variations in the physiological profiles of streambed bacterial communities impacted by WWTP effluents. In conclusion, our data show that WWTP effluent is a relevant source of nutrients once the wastewater effluent is released into the river. WWTP effluents significantly increased microbial biomass and modified bacterial community structure and diversity in several ways. The mixed effects of effluents on microbial community structure stresses the need for more studies to fully understand the impact of WWTP effluents on river ecosystems and in the designing of WWTP management plans. This study also indicates a close association between sedimentary physicochemical parameters (temperature, percent moisture, and organic matter contents) and the associated microbial functional activities. Seasonal and site-specific composition changes were observed in the substrate utilization patterns of bacterial communities. Communities in fall showed more versatile substrate utilization patterns than that of the winter communities. Physiological profiling of 
bacterial communities is thus crucial for a better understanding of the biodegradation potential of stream bacterial communities as they differ in responses to a range of carbon sources.

\section{Declarations}

\section{Acknowledgments}

We would like to thank Wendy Tomamichel for laboratory and technical support. DePauw students; Anya Sanders and Emma Arndt helped with sample collections and processing. We also thank Steve Taylor for initial ground-truthing and site identification on the Big Walnut Creek. Funding was provided by DePauw Science Research Fellows Program (to MD and SA), the Douglas A. and Phyllis G. Smith Endowed Fund for Student-Faculty Research, and the Faculty Development Program (to AG and PA), and Asher Fund in the sciences (to PA).

The authors declare that the research was conducted in the absence of any commercial or financial relationships that could be construed as a potential conflict of interest. PA contributed to the conception and design of the study; PA, MD, and SA sampled Big Walnut Creek; PA, MD, and AG performed statistical analyses; PA, MD, and AG wrote the manuscript; SA, PA, MD, and AG reviewed and edited the manuscript. All authors contributed to manuscript revision, read, and approved the submitted version.

\section{References}

Akinwole P, Kaplan L, Findlay R (2021) Elucidating stream bacteria utilizing terrestrial dissolved organic matter. World J Microbiol Biotechnol 37(2):1-13

Araya R, Tani K, Takagi T, Yamaguchi N, Nasu M (2003) Bacterial activity and community composition in stream water and biofilm from an urban river determined by fluorescent in situ hybridization and DGGE analysis. FEMS Microbiol Ecol 43(1):111-119

Aristi I, Schiller D von, Arroita M, Barceló D, Ponsatí L, García-Galán MJ, Sabater S, Elosegi A, Acuña V (2015) Mixed effects of effluents from a wastewater treatment plant on river ecosystem metabolism: Subsidy or stress? Freshw Biol 60(7):1398-1410

Artigas J, Romani AM, Gaudes A, Munoz I, Sabater S (2009) Organic matter availability structures microbial biomass and activity in a Mediterranean stream. Freshw Biol 54(10):2025-2036

Autio R (1998) Response of seasonally cold-water bacterioplankton to temperature and substrate treatments. Estuar Coast Shelf Sci 46:465-474

Battin TJ, Besemer K, Bengtsson MM, Romani AM, Packmann Al (2016) The ecology and biogeochemistry of stream biofilms. Nat Rev Microbiol 14:251-263 
Battin TJ, Kaplan LA, Newbold JD, Hendricks SP (2003) A mixing model analysis of stream solute dynamics and the contribution of a hyporheic zone to ecosystem function. Freshw Biol 48(6):995-1014

Benfield EF (1997) Comparison of litterfall input to streams. J North Am Benthol Soc 16(1):104-108

Böckelmann U, Manz W, Neu TR, Szewzyk U (2000) Characterization of the microbial community of lotic organic aggregates ('river snow') in the Elbe River of Germany by cultivation and molecular methods. FEMS Microbiol Ecol 33(2):157-170

Brummer IHM, Fehr W, Wagner-Dobler I (2000) Biofilm community structure in polluted rivers: abundance of dominant phylogenetic groups over a complete annual cycle. Appl Environ Microbiol 66:3078-3082

Bueno MJM, Gomez MJ, Herrera S, Hernando MD, Agüera A, Fernández-Alba AR (2012) Occurrence and persistence of organic emerging contaminants and priority pollutants in five sewage treatment plants of Spain: Two years pilot survey monitoring. Environ Pollut 164: 267-273

Button M, Nivala J, Weber KP, Aubron T, Müller RA (2015) Microbial community metabolic function in subsurface flow constructed wetlands of different designs. Ecol Eng 80:162-171

Cebron A, Coci M, Garnier J, Laanbroek HJ (2004) Denaturing Gradient Gel Electrophoretic Analysis of Ammonia-Oxidizing Bacterial Community Structure in the Lower Seine River: Impact of Paris Wastewater Effluents. Appl Environ Microbiol 70(11):6726-6737

Dang Q, Tan W, Zhao X, Li D, Li Y, Yang T, Li R, Zu G, Xi B (2019) Linking the response of soil microbial community structure in soils to long-term wastewater irrigation and soil depth. Sci Total Environ 688:2636

Drury B, Rosi-Marshall E, Kelly JJ (2013) Wastewater treatment effluent reduces the abundance and diversity of benthic bacterial communities in urban and suburban rivers. Appl Environ Microbiol 79(6):1897-1905

Elósegui A, Arana X, Basaguren A, Pozo J (1995) Self-purification processes along a medium-sized stream. Environ Manage 19(6):931-939

Englert D, Zubrod JP, Schulz R, Bundschuh M (2013) Effects of municipal wastewater on aquatic ecosystem structure and function in the receiving stream. Sci Total Environ 454-455:401-410

Feris KP, Ramsey PW, Frazar C, Rillig MC, Gannon JE, Holben WE (2003) Structure and seasonal dynamics of hyporheic zone microbial communities in free-stone rivers of the western United States. Microb Ecol 46:200-215

Findlay RH, King GM, Watling L (1989) Efficacy of Phospholipid Analysis in Determining Microbial Biomass in Sediments. Appl Environ Microbiol 55(11):2888-2893 
Findlay S, Tank J, Dye S, Valett HM, Mulholland PJ, McDowell WH, Bowden WB (2002) A cross-system comparison of bacterial and fungal biomass in detritus pools of headwater streams. Microb Ecol 43(1):55-66

Gammon JR (1994) The status of riparian wetlands in west-central Indiana streams. Proc Indiana Acad Sci 103(3-4):195-214

Garland JL, Mills AL (1991) Classification and characterization of heterotrophic microbial communities on the basis of patterns of community-level sole-carbon-source utilization. Appl Environ Microbiol 57(8):2351-2359

Gremm TJ, Kaplan LA (1998) Dissolved carbohydrate concentration, composition, and bioavailability to microbial heterotrophs in stream water. Acta Hydrochim Hydrobiol 26(3):167-171

Gryta A, Frąc M, Oszust K (2014) The Application of the Biolog EcoPlate approach in ecotoxicological evaluation of dairy sewage sludge. Appl Biochem Biotechnol 174(4):1434-1443

Guo Z, Han J, Li J, Xu Y, Wang X (2019) Effects of long-term fertilization on soil organic carbon mineralization and microbial community structure. PLOS ONE 14(1):e0211163.

Harbott EL, Grace MR (2005) Extracellular enzyme response to bioavailability of dissolved organic $C$ in streams of varying catchment urbanization. J North Am Benthol Soc 24(3):588-601

Harch BD, Correll RL, Meech W, Kirkby CA, Pankhurst CE (1997) Using the Gini coefficient with BIOLOG substrate utilisation data to provide an alternative quantitative measure for comparing bacterial soil communities. J Microbiol Methods 30(1):91-1011

Hullar MA, Kaplan LA, Stahl DA (2006) Recurring seasonal dynamics of microbial communities in stream habitats. Appl Environ Microbiol 72(1):713-722

Jałowiecki Ł, Chojniak JM, Dorgeloh E, Hegedusova B, Ejhed H, Magnér J, Płaza GA (2016) Microbial community profiles in wastewaters from onsite wastewater treatment systems technology. PLOS ONE 11(1):e0147725

Khan FA, Söderquist B, Jass J (2019) Prevalence and diversity of antibiotic resistance genes in swedish aquatic environments impacted by household and hospital wastewater. Front Microbiol 10, 688

Kunhikrishnan A, Choppala G, Seshadri B, Wijesekara H, Bolan NS, Mbene K, Kim WI (2017) Impact of wastewater derived dissolved organic carbon on reduction, mobility, and bioavailability of $\mathrm{As}(\mathrm{V})$ and $\mathrm{Cr}(\mathrm{VI})$ in contaminated soils. J Environ Manage 186:183-191

Lu XM, Lu PZ (2014) Characterization of bacterial communities in sediments receiving various wastewater effluents with high-throughput sequencing analysis. Micro Ecol 67(3):612-623 
Ma X, Liu M, Li Z (2015) Changes in microbial properties and community composition in acid soils receiving wastewater from concentrated animal farming operations. Appl Soil Ecol 90:11-17

Magesan GN, Williamson JC, Yeates GW, Lloyd-Jones AR (2000) Wastewater C:N ratio effects on soil hydraulic conductivity and potential mechanisms for recovery. Bioresour Technol 71(1):21-27

Manz W, Eisenbrecher M, Neu TR, Szewzyk U (1998) Abundance and spatial organization of Gramnegative sulfate-reducing bacteria in activated sludge investigated by in situ probing with specific $16 \mathrm{~S}$ rRNA targeted oligonucleotides. FEMS Microbiol Ecol 25(1):43-61

Mosher JJ, Findlay RH (2011) Direct and indirect influence of parental bedrock on streambed microbial community structure in forested streams. Appl Environ Microbiol 77(21):7681-7688

Muñiz S, Lacarta J, Pata MP, Jiménez JJ, Navarro E (2014) Analysis of the Diversity of Substrate Utilisation of Soil Bacteria Exposed to $\mathrm{Cd}$ and Earthworm Activity Using Generalised Additive Models. PLOS ONE 9(1):e85057

Nagy ZM, Gruiz K, Molnár M, Fenyvesi É (2013) Comparative evaluation of microbial and chemical methods for assessing 4-chlorophenol biodegradation in soil. Period Polytech Chem Eng 57(1-2):25-35

Nájera AF, Serwecińska L, Szklarek S, Mankiewicz-Boczek J (2020) Characterization and comparison of microbial communities in sequential sedimentation-biofiltration systems for removal of nutrients in urban rivers. Ecol Eng 149:105796

Nega M, Braun B, Künzel S, Szewzyk U (2019) Evaluating the impact of wastewater effluent on microbial communities in the Panke, an Urban River. Water 11(5):888

Oest A, Alsaffar A, Fenner M, Azzopardi D, Tiquia-Arashiro SM (2018) Patterns of change in metabolic capabilities of sediment microbial communities in river and lake ecosystems. Int J Microbiol 2018

Olapade OA, Leff LG (2004) Seasonal dynamics of bacterial assemblages in epilithic biofilms in a northeastern Ohio stream. J North Am Benthol Soc 23(4):686-700

Preston-Mafham L, Boddy L, Randerson PF (2002) Analysis of microbial community functional diversity using sole-carbon-source utilisation profiles-a critique. FEMS Microbiol Ecol. 42(1): 1-14.

Rosenstock B, Simon M (2003) Consumption of dissolved amino acids and carbohydrates by limnetic bacterioplankton according to molecular weight fractions and proportions bound to humic matter. Microb Ecol 45(4):433-443

Sabater F, Butturini A, Martí E, Muñoz I, Romaní A, Wray J, Sabater S (2000) Effects of riparian vegetation removal on nutrient retention in a Mediterranean stream. J North Am Benthol Soc 19(4):609-620 
Sabri NA, Schmitt H, Van der Zaan B, Gerritsen HW, Zuidema T, Rijnaarts HHM, Langenhoff AAM (2020) Prevalence of antibiotics and antibiotic resistance genes in a wastewater effluent-receiving river in the Netherlands. J Environ Chem Eng 8(1):102245

Schloter M, Dilly O, Munch JC (2003) Indicators for evaluating soil quality. Agric Ecosyst Environ 98(1):255-262

Sekiguchi H, Watanabe M, Nakahara T, Xu B, Uchiyama H (2002) Succession of bacterial community structure along the Changjiang River determined by denaturing gradient gel electrophoresis and clone library analysis. Appl Environ Microbiol 68:5142-5150

Smoot JC, Findlay RH (2001) Spatial and seasonal variation in a reservoir sedimentary microbial community as determined by phospholipid analysis. Microb Ecol 42:350-358

Suberkropp K (1997) Annual production of leaf-decaying fungi in a woodland stream. Freshw Biol 38(1):169-178

Tao Y, Dai T, Huang B, Wen D (2017) The impact of wastewater treatment effluent on microbial biomasses and diversities in coastal sediment microcosms of Hangzhou Bay. Mar Pollut Bull 114(1):355-363r

Tank JL, Rosi-Marshall EJ, Griffiths NA, Entrekin SA, Stephen ML (2010) A review of allochthonous organic matter dynamics and metabolism in streams. J North Am Benthol Soc 29(1):118-146

Tiquia SM (2010) Metabolic diversity of the heterotrophic microorganisms and potential link to pollution of the Rouge River. Environ Pollut 158(5):1435-1443

Tiquia SM, Schleibak M, Schlaff J, Floyd C, Benipal B, Zakhem E, Murray KS (2008) Microbial community profiling and characterization of some heterotrophic bacterial isolates from river waters and shallow groundwater wells along the Rouge River, Southeast Michigan. Environ Tech 29(6): 651-663

Treves DS, Xia B, Zhou J, Tiedje JM (2003) A two-species test of the hypothesis that spatial isolation influences microbial diversity in soil. Microb Ecol 45(1), 20-28

Urakawa H, Ali J, Ketover RD, Talmage SD, Garcia JC, Campbell IS, Parsons ML (2013) Shifts of bacterioplankton metabolic profiles along the salinity gradient in a subtropical estuary. ISRN 2013

Von Schiller D, Martí E, Riera JL, Ribot M, Marks JC, Sabater F (2008) Influence of land use on stream ecosystem function in a Mediterranean catchment. Freshw Biol 53(12):2600-2612

Wakelin SA, Colloff MJ, Kookana RS (2008) Effect of wastewater treatment plant effluent on microbial function and community structure in the sediment of a freshwater stream with variable seasonal flow. Appl Environ Microbiol 74(9):2659-2668 
Wang Y, Shi J, Wang H, Lin Q, Chen X, Chen Y (2007a) The influence of soil heavy metals pollution on soil microbial biomass, enzyme activity, and community composition near a copper smelter. Ecotoxicol Environ Saf 67(1):75-81

Wang YP, Houlton BZ, Field CB (2007b) A model of biogeochemical cycles of carbon, nitrogen, and phosphorus including symbiotic nitrogen fixation and phosphatase production. Global Biogeochem Cycles 21(1)

Wang M, Shen W, Yan L, Wang X-H, Xu H (2017) Stepwise impact of urban wastewater treatment on the bacterial community structure, antibiotic contents, and prevalence of antimicrobial resistance. Environ Pollut 231:1578-1585

Weber KP, Legge RL (2009) One-dimensional metric for tracking bacterial community divergence using sole carbon source utilization patterns. J Microbiol Method 79(1):55-61

Zeglin LH (2015) Stream microbial diversity in response to environmental changes: review and synthesis of existing research. Front Microbiol 6:454

\section{Tables}

Table 1 Seasonal means ( \pm SD) of the total microbial biomass, H-index, percentages of organic carbon $(\% \mathrm{C})$ and organic nitrogen $(\% \mathrm{~N})$ contents, $\mathrm{C} / \mathrm{N}$ mass ratio, and temperature of the Big Walnut Creek collected in 2019 (September and October) and 2020 (February). 


\begin{tabular}{|c|c|c|c|c|c|c|c|}
\hline \begin{tabular}{l|l}
$y$ & Site \\
&
\end{tabular} & $\begin{array}{l}\begin{array}{l}\text { Biomass } \\
\text { (nmol PO4 } \\
\text { gdw) }\end{array} \\
\end{array}$ & $\begin{array}{l}\mathrm{H}- \\
\text { Index }\end{array}$ & $\begin{array}{l}\text { Temperature } \\
\left({ }^{\circ} \mathrm{C}\right)\end{array}$ & $\% \mathrm{~N}$ & $\% \mathrm{C}$ & $\begin{array}{l}\mathrm{C} / \mathrm{N} \\
\text { ratio }\end{array}$ & $\begin{array}{l}\% \\
\text { Moisture } \\
\text { Content }\end{array}$ \\
\hline DCB & $32.42 \pm 2.00$ & $\begin{array}{l}3.38 \\
\pm \\
0.03\end{array}$ & $\begin{array}{l}23.51 \pm \\
0.15\end{array}$ & $\begin{array}{l}0.042 \\
\pm \\
0.003\end{array}$ & $\begin{array}{l}1.61 \pm \\
0.24\end{array}$ & $\begin{array}{l}38.30 \\
\pm 2.72\end{array}$ & 46.57 \\
\hline WWU & $23.81 \pm 5.83$ & $\begin{array}{l}3.36 \\
\pm \\
0.02\end{array}$ & $\begin{array}{l}23.22 \pm \\
0.01\end{array}$ & $\begin{array}{l}0.025 \\
\pm \\
0.001\end{array}$ & $\begin{array}{l}1.19 \pm \\
0.14\end{array}$ & $\begin{array}{l}47.42 \\
\pm 5.20\end{array}$ & 45.00 \\
\hline WWD & $38.63 \pm 5.50$ & $\begin{array}{l}3.39 \\
\pm \\
0.01\end{array}$ & $\begin{array}{l}23.35 \pm \\
0.09\end{array}$ & $\begin{array}{l}0.043 \\
\pm \\
0.001\end{array}$ & $\begin{array}{l}1.63 \pm \\
0.14\end{array}$ & $\begin{array}{l}37.73 \\
\pm 2.16\end{array}$ & 39.52 \\
\hline NP & $29.33 \pm 2.60$ & $\begin{array}{l}3.28 \\
\pm \\
0.13\end{array}$ & $\begin{array}{l}23.74 \pm \\
0.18\end{array}$ & $\begin{array}{l}0.026 \\
\pm \\
0.002\end{array}$ & $\begin{array}{l}1.02 \pm \\
0.08\end{array}$ & $\begin{array}{l}39.62 \\
\pm 0.71\end{array}$ & 33.36 \\
\hline OCB & $31.25 \pm 6.01$ & $\begin{array}{l}3.30 \\
\pm \\
0.05\end{array}$ & $\begin{array}{l}23.35 \pm \\
0.01\end{array}$ & $\begin{array}{l}0.034 \\
\pm \\
0.002 \\
\end{array}$ & $\begin{array}{l}1.49 \pm \\
0.61\end{array}$ & $\begin{array}{l}43.41 \\
\pm \\
15.77 \\
\end{array}$ & 42.23 \\
\hline$\overline{\mathrm{DCB}}$ & $75.75 \pm 2.09$ & $\begin{array}{l}3.36 \\
\pm \\
0.04\end{array}$ & $\begin{array}{l}12.90 \pm \\
1.04\end{array}$ & $\begin{array}{l}0.042 \\
\pm \\
0.003\end{array}$ & $\begin{array}{l}1.54 \pm \\
0.12\end{array}$ & $\begin{array}{l}36.57 \\
\pm 0.46\end{array}$ & 61.62 \\
\hline WWU & $\begin{array}{l}84.54 \pm \\
20.16\end{array}$ & $\begin{array}{l}3.34 \\
\pm \\
0.05\end{array}$ & $\begin{array}{l}12.50 \pm \\
0.30\end{array}$ & $\begin{array}{l}0.062 \\
\pm \\
0.003\end{array}$ & $\begin{array}{l}2.51 \pm \\
0.02\end{array}$ & $\begin{array}{l}40.29 \\
\pm 2.00\end{array}$ & 55.00 \\
\hline WWD & $\begin{array}{l}87.60 \pm \\
25.07\end{array}$ & $\begin{array}{l}3.38 \\
\pm \\
0.04\end{array}$ & $\begin{array}{l}13.97 \pm \\
0.81\end{array}$ & $\begin{array}{l}0.056 \\
\pm \\
0.009\end{array}$ & $\begin{array}{l}2.41 \pm \\
0.11\end{array}$ & $\begin{array}{l}43.18 \\
\pm 4.83\end{array}$ & 69.84 \\
\hline NP & $54.97 \pm 2.34$ & $\begin{array}{l}3.26 \\
\pm \\
0.23\end{array}$ & $\begin{array}{l}12.60 \pm \\
0.56\end{array}$ & $\begin{array}{l}0.028 \\
\pm \\
0.001\end{array}$ & $\begin{array}{l}1.73 \pm \\
0.15\end{array}$ & $\begin{array}{l}61.74 \\
\pm 1.94\end{array}$ & 30.00 \\
\hline OCB & $\begin{array}{l}113.59 \pm \\
13.93\end{array}$ & $\begin{array}{l}3.26 \\
\pm \\
0.15\end{array}$ & $\begin{array}{l}12.50 \pm \\
0.26\end{array}$ & $\begin{array}{l}0.038 \\
\pm \\
0.002 \\
\end{array}$ & $\begin{array}{l}1.17 \pm \\
0.005\end{array}$ & $\begin{array}{l}30.75 \\
\pm 1.24\end{array}$ & 29.64 \\
\hline$\overline{\mathrm{DCB}}$ & $2.37 \pm 0.45$ & $\begin{array}{l}2.82 \\
\pm \\
0.08\end{array}$ & $1.07 \pm 0.06$ & $\begin{array}{l}0.010 \\
\pm \\
0.001\end{array}$ & $\begin{array}{l}0.847 \\
\pm \\
0.300\end{array}$ & $\begin{array}{l}84.54 \\
\pm \\
21.92\end{array}$ & 27.12 \\
\hline WWU & $6.56 \pm 0.49$ & $\begin{array}{l}3.27 \\
\pm \\
0.02\end{array}$ & $1.50 \pm 0.10$ & $\begin{array}{l}0.018 \\
\pm \\
0.001\end{array}$ & $\begin{array}{l}1.11 \pm \\
0.03\end{array}$ & $\begin{array}{l}60.44 \\
\pm 0.27\end{array}$ & 23.21 \\
\hline WWD & $16.27 \pm 2.40$ & $\begin{array}{l}3.34 \\
\pm \\
0.03\end{array}$ & $3.60 \pm 0.20$ & $\begin{array}{l}0.019 \\
\pm \\
0.001\end{array}$ & $\begin{array}{l}1.07 \pm \\
0.10\end{array}$ & $\begin{array}{l}56.84 \\
\pm 3.53\end{array}$ & 28.48 \\
\hline NP & $1.28 \pm 0.50$ & $\begin{array}{l}2.24 \\
\pm \\
1.23\end{array}$ & $2.53 \pm 0.25$ & $\begin{array}{l}0.011 \\
\pm \\
0.004\end{array}$ & $\begin{array}{l}0.72 \pm \\
0.14\end{array}$ & $\begin{array}{l}66.49 \\
\pm \\
10.62\end{array}$ & 21.30 \\
\hline OCB & $9.03 \pm 1.02$ & $\begin{array}{l}3.22 \\
\pm \\
0.15\end{array}$ & $2.87 \pm 0.47$ & $\begin{array}{l}0.031 \\
\pm \\
0.004\end{array}$ & $\begin{array}{l}1.49 \pm \\
0.26\end{array}$ & $\begin{array}{l}47.35 \\
\pm 2.28\end{array}$ & 25.33 \\
\hline
\end{tabular}

Means corresponded to 3 values for microbial biomass, H-index, and temperature, and to 2 values for $\% \mathrm{~N}, \% \mathrm{C}$ and $\mathrm{C} / \mathrm{N}$ ratio. 
Table 2 Results of 2 -way analysis of variance of the effects of the season (sampling dates) vs. site on total microbial biomass (log-transformed), H - Index, and some physico-chemical parameters of the Big Walnut Creek.

\begin{tabular}{r|llll}
\multicolumn{1}{r}{ Parameter } & Factor & df & F & $\boldsymbol{p}$ \\
\hline Biomass (nmol $\mathrm{PO}_{4}$ gdw) & Site & 4 & 39.563 & $<0.001$ \\
\cline { 2 - 5 } & Season & 2 & 1003.486 & $<0.001$ \\
\cline { 2 - 5 } H-Index & Site x Season & 8 & 4.456 & 0.001 \\
\cline { 2 - 5 } & Site & 4 & 5.640 & 0.065 \\
& Season & 2 & 2.470 & 0.008 \\
\cline { 2 - 5 } & Site x Season & 8 & 1.695 & 0.141 \\
\cline { 2 - 5 }$\% \mathrm{C}$ & Site & 4 & 26.297 & $<0.001$ \\
& Season & 2 & 186.432 & $<0.001$ \\
\cline { 2 - 5 } & Site x Season & 8 & 20.203 & $<0.001$ \\
\cline { 2 - 5 } & Site & 4 & 6.126 & 0.004 \\
& Season & 2 & 36.977 & $<0.001$ \\
\cline { 2 - 5 } Temperature $\left({ }^{\circ} \mathrm{C}\right)$ & Site x Season & 8 & 7.470 & $<0.001$ \\
\cline { 2 - 5 } & Site & 4 & 3.557 & 0.031 \\
& Season & 2 & 24.248 & $<0.001$ \\
\cline { 2 - 5 } & Site x Season & 8 & 3.779 & 0.013 \\
\hline & Site & 4 & 12.331 & $<0.001$ \\
& Season & 2 & $9,590.704$ & $<0.001$ \\
\cline { 2 - 5 } & Site x Season & 8 & 6.586 & $<0.001$ \\
\hline
\end{tabular}

Table 3 The results of the Best Subsets regression analysis looking at the effects of independent variables: Temperature, $\% \mathrm{C}, \% \mathrm{~N}$, and C:N ratio on sedimentary (log) microbial biomass and bacterial community structure (PC1). 


\begin{tabular}{c|lcl}
\hline Model/Number of variables & Independent variables: & $\boldsymbol{R}$ & $\boldsymbol{R}^{\mathbf{2}}$ \\
\hline \begin{tabular}{c|l} 
Microbial Biomass \\
1
\end{tabular} & \%N & 0.81 & $0.66^{* *}$ \\
2 & \%C, C:N & 0.86 & $0.74^{* *}$ \\
3 & Temperature, \%C, C:N & 0.87 & $0.75^{* *}$ \\
4 & Temperature, \%N, \%C, C:N & 0.87 & $0.75^{* *}$ \\
\hline Community structure (PC1) & \%N & 0.63 & $0.39^{* *}$ \\
1 & \%C, C/N Ratio & 0.71 & $0.50^{* *}$ \\
2 & Temperature, \%C, C/N & 0.74 & $0.55^{* *}$ \\
3 & Temperature, \%N, \%C, C/N & 0.76 & $0.57^{* *}$ \\
\hline 4
\end{tabular}

** significant at $\mathrm{P}<0.001$

Table 4 Results of three-way ANOVA looking at the effects of the season (sampling date), site, and guild on the AWCD/bacterial carbon utilization.

\begin{tabular}{|c|c|c|c|c|}
\hline \multirow{2}{*}{$\begin{array}{r}\text { Factors } \\
\text { Season }\end{array}$} & df & $\mathbf{F}$ & $\mathbf{p}$ & post hoc (Fisher LSD) \\
\hline & 2 & 113.245 & $<$ & Oct $=$ Sept $>$ Feb $^{* *}$ \\
\hline \multirow{3}{*}{ Site } & & & 0.0001 & \\
\hline & 4 & 32.791 & $<$ & $\mathrm{WWD}=\mathrm{OCB}, \mathrm{WWU}=\mathrm{OCB}, \mathrm{NP}<\mathrm{WWU}<\mathrm{WWD} * *$, \\
\hline & & & 0.0001 & $\mathrm{DCB}=\mathrm{WWU}, \mathrm{NP}<\mathrm{DCB}<\mathrm{OCB}=\mathrm{WWD} * *$ \\
\hline \multirow[t]{2}{*}{ Guild } & 4 & 5.502 & $<$ & Carb $>$ AA $>$ Poly**, C\&AA $>$ Polymer** \\
\hline & & & 0.0001 & \\
\hline \multirow[t]{2}{*}{ Season $\mathrm{x}$ site } & 8 & 27.280 & $<$ & DCB, NP (Feb vs Oct, Feb vs Sept**, Oct vs Sept \\
\hline & & & 0.0001 & ns); WWU, WWD, OCB (season ns) \\
\hline $\begin{array}{r}\text { Season x } \\
\text { Guild }\end{array}$ & 8 & 1.193 & 0.30 & ns \\
\hline Site x Guild & 16 & 0.647 & 0.85 & ns \\
\hline \multirow{2}{*}{$\begin{array}{r}\text { Season x site } \\
\text { x Guild }\end{array}$} & 32 & 0.766 & 0.82 & ns \\
\hline & & & & \\
\hline
\end{tabular}

Abbreviations - AWCD: average well color development, Carb: Carbohydrate, AA: Amino acid, Poly: Polymer, C\&AA: Carboxylic acid and acetic acid, A\&A: Amine and amides, ns: not significant at level $P<0.05$, ** significant at $\mathrm{P}<0.001$,

\section{Figures}




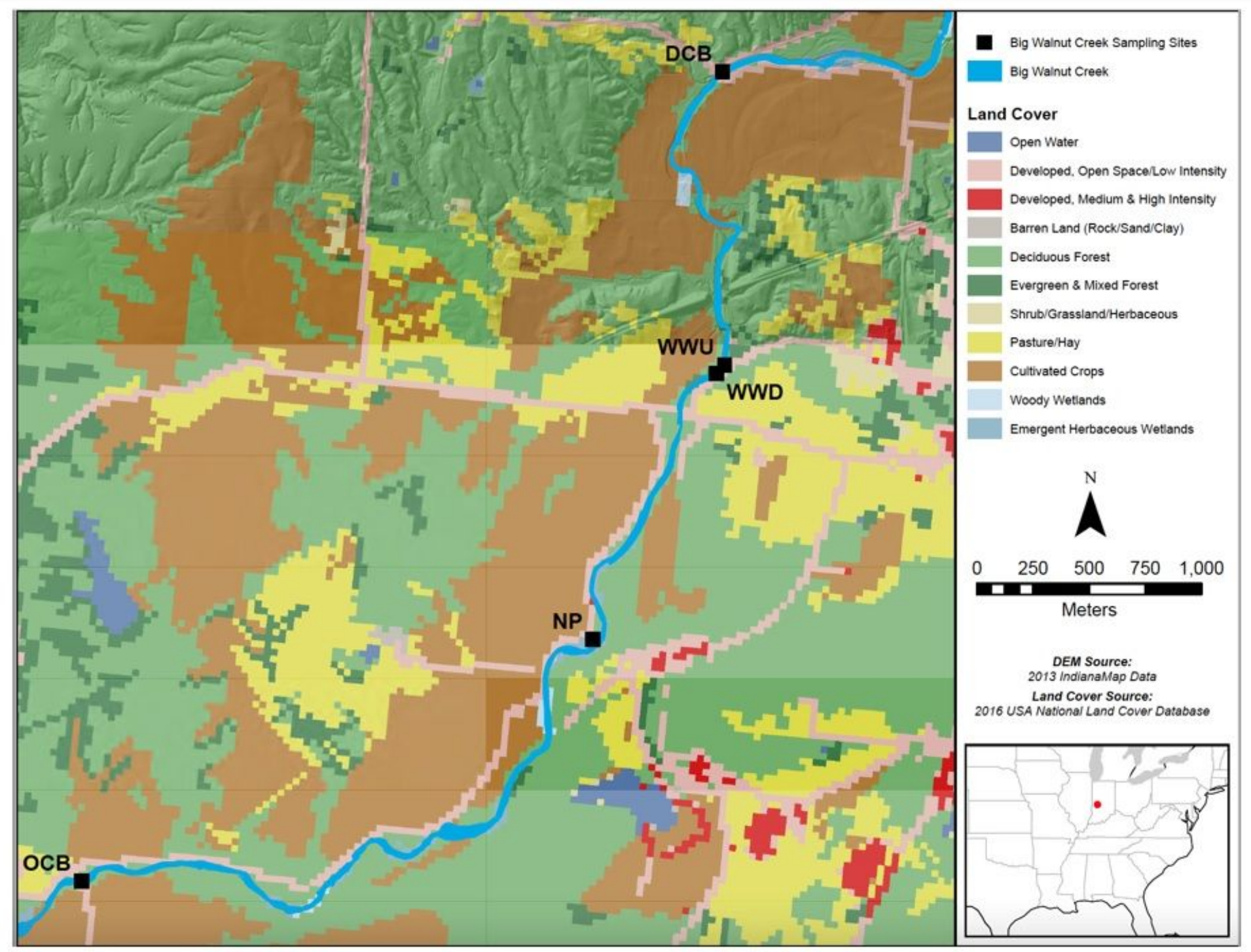

\section{Figure 1}

Sampling site locations and land cover classes along the Big Walnut Creek, Greencastle, IN. Locations: $\mathrm{DCB}=$ Dunbar Covered Bridge, WWU = Wastewater Treatment Upstream, WWD = Wastewater Treatment Downstream, NP = Nature Park, and OCB = Ocalla Covered Bridge. 


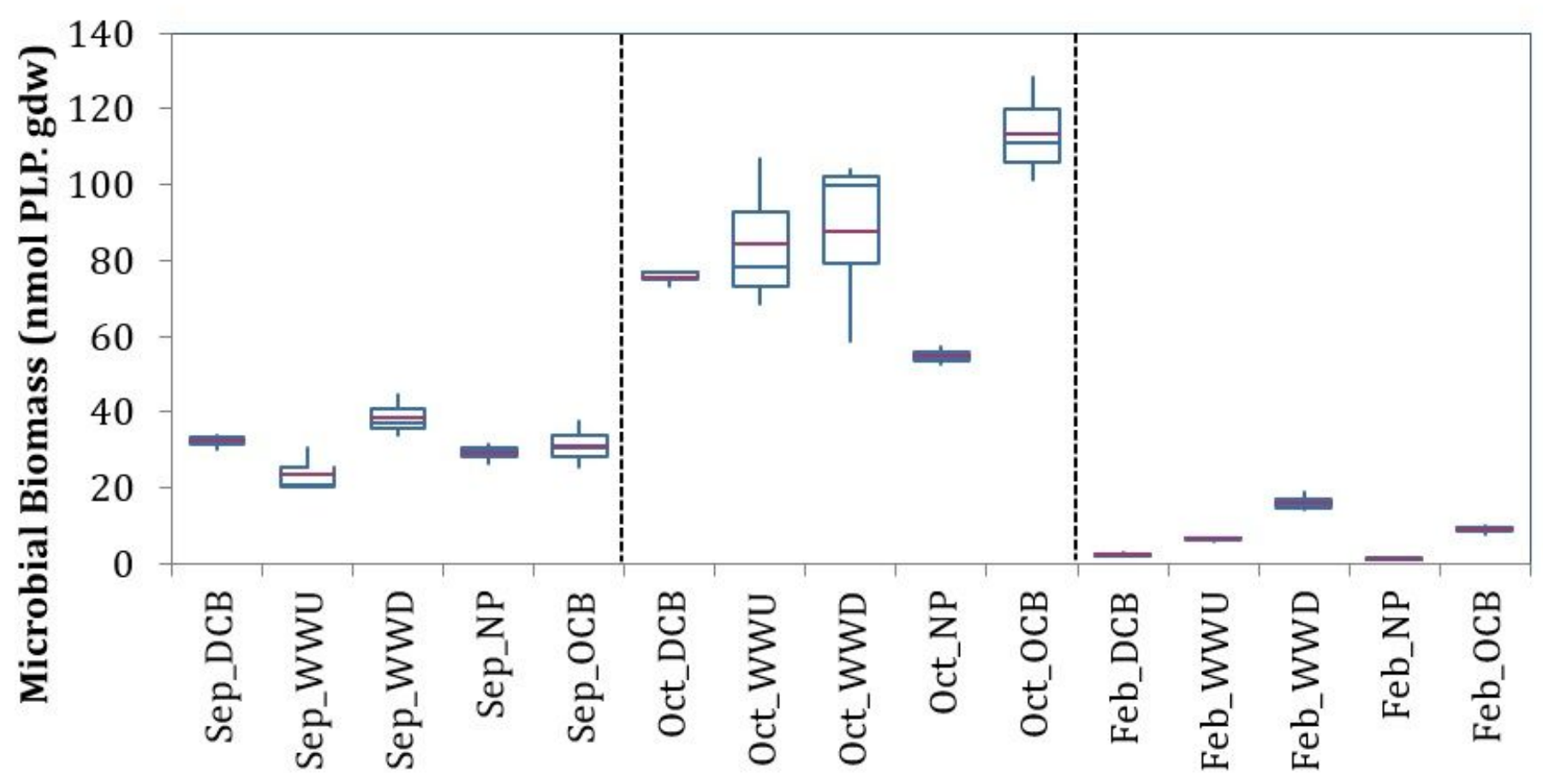

Sampling Date by Site

Figure 2

Box plot of seasonal change in sedimentary total microbial biomass at different sites along the Big Walnut Creek measured by phospholipid phosphate method. Locations: DCB = Dunbar Covered Bridge, WWU = Wastewater treatment upstream, WWD = Wastewater treatment downstream, NP = Nature Park, and OCB = Ocalla Covered Bridge. Sampling Date: Sep $=$ September 2019, Oct $=$ October 2019, Feb = February 2020. $n=3(p<0.001)$. The red line inside the rectangle indicate the mean of the sample distribution. The upper and lower boundaries of each rectangle indicate the upper quartile and lower quartile respectively. The upper and lower whiskers are the upper and lower extreme values respectively. 


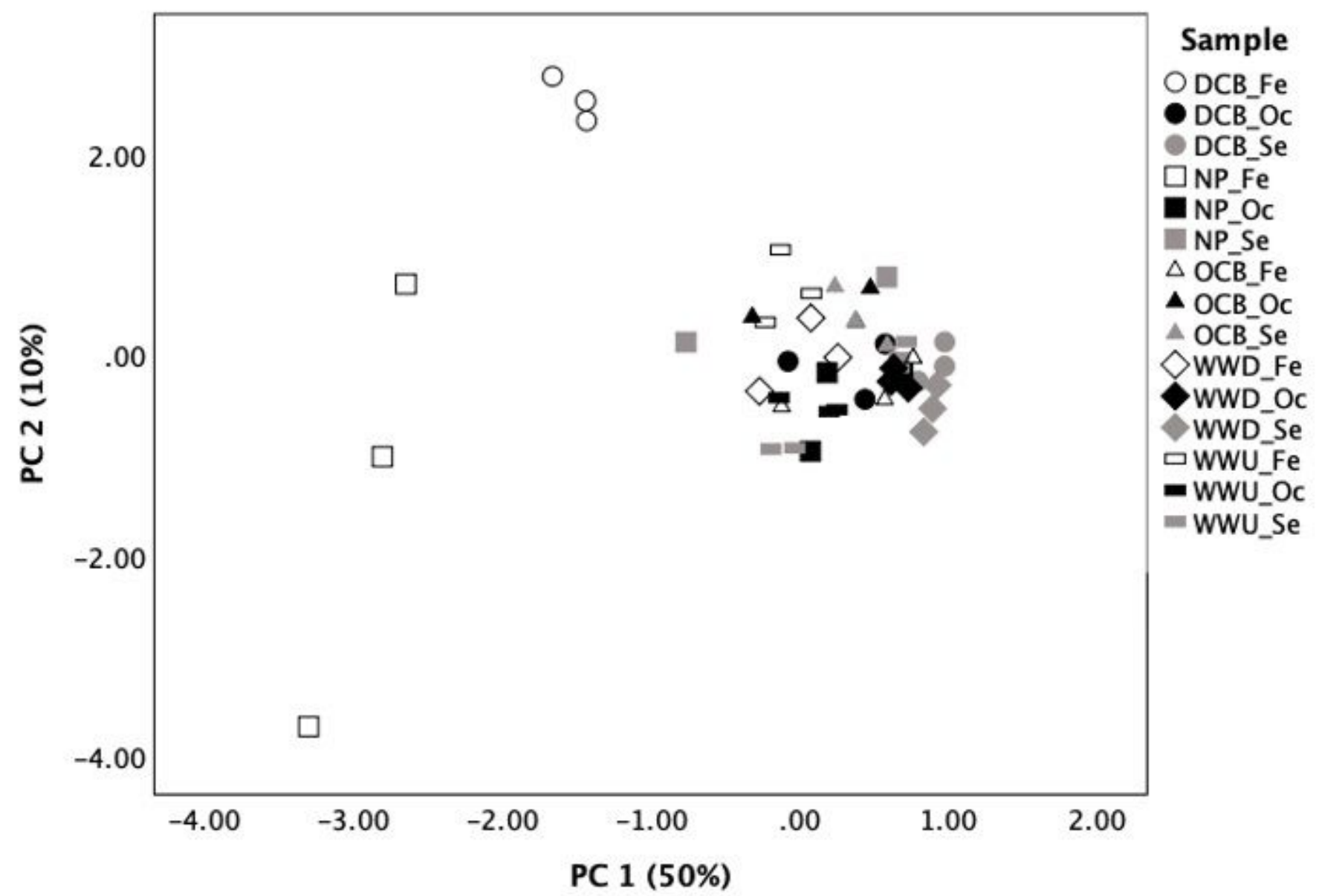

Figure 3

Principal component analysis of 120-h OD590 readings taken from Biolog EcoPlates of the sedimentary bacterial community structure of the Big Walnut Creek seasonal sampling site. The percentage in parentheses after the principal components indicate the percentage of total variance explained by each principal component. Scores are plotted by site and month. Se= September 2019; Oc= October 2019; $\mathrm{Fe}=$ February 2020. 


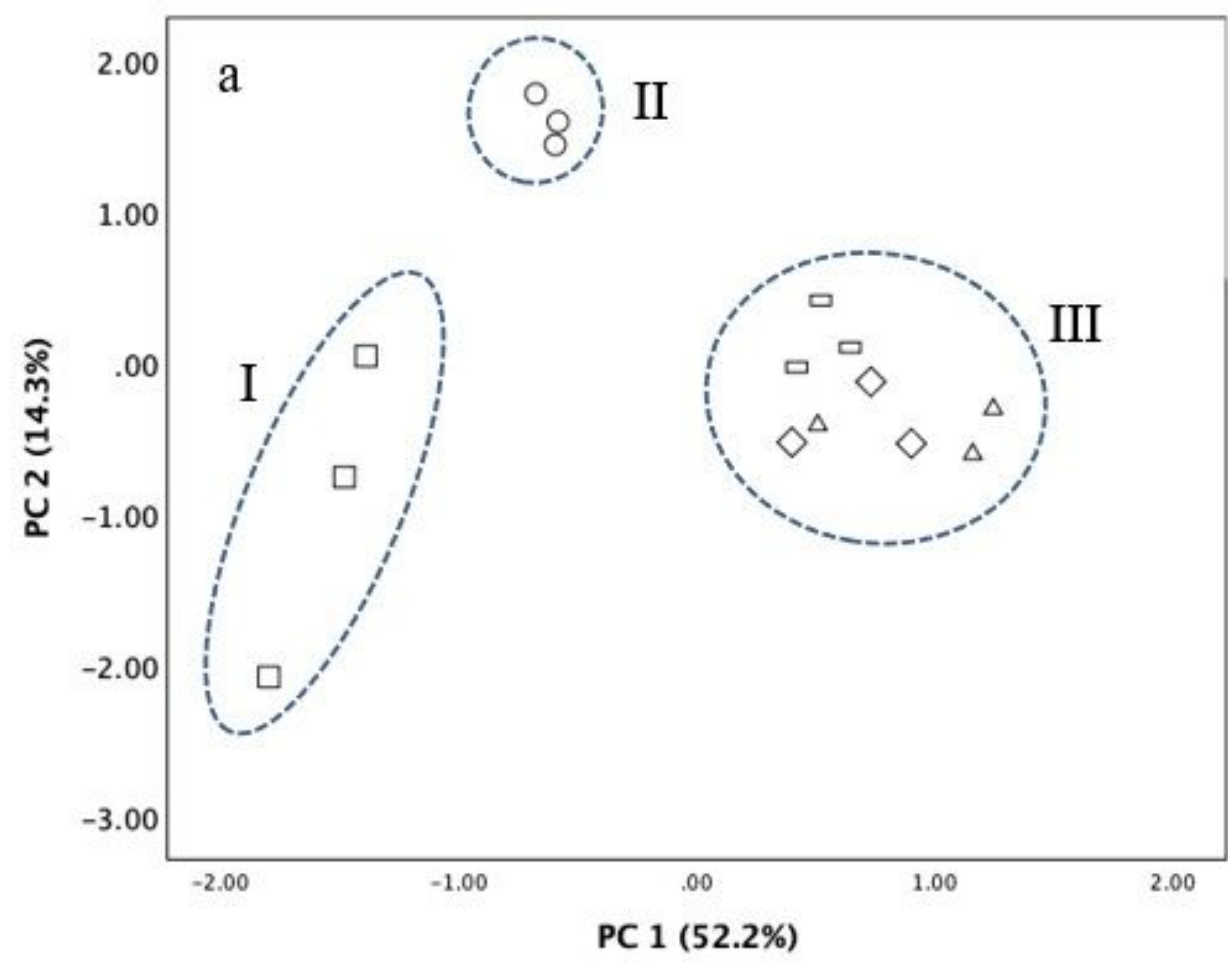

Sample

ODCB_Fe

$\square \mathrm{NP} F \mathrm{Fe}$

$\triangle$ OCB_Fe

$\triangle$ WWD_Fe

口WWUFe

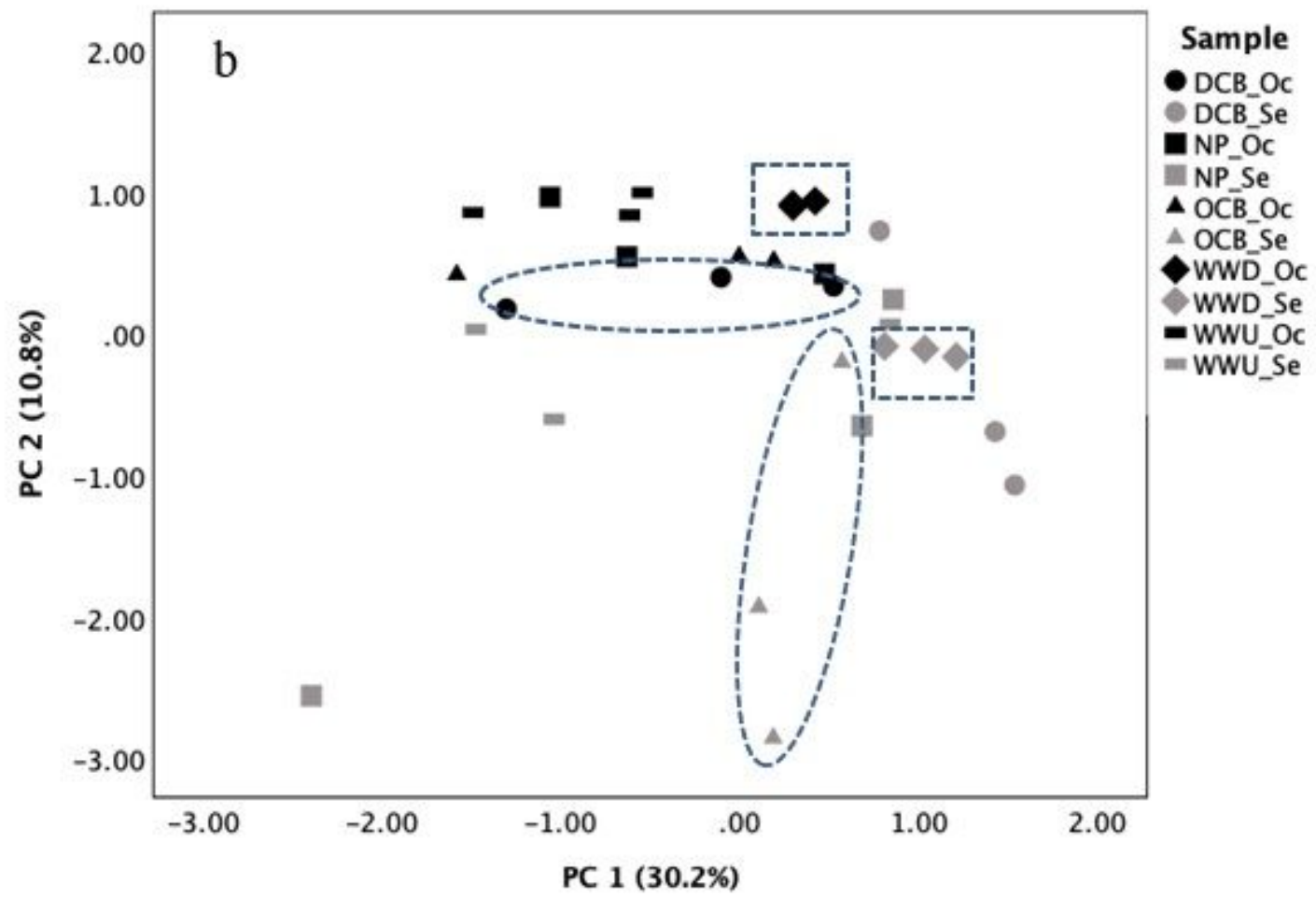

Figure 4

Spatial variation in sedimentary bacterial community composition in the context of WWTP impact. a) PCA analysis of bacterial physiological profiles during the period of cold water: after removal of samples collected in warmer water (Sept and Oct. 2019). b) PCA analysis of bacterial physiological profiles during the period of warmer water: after removal of samples collected in cold water (Feb. 2020). Dashed squares indicate the relative variation in bacterial community structure of WWD stream sediments and dashed 
spheres indicate the same for OCB and DCB in September and October 2019 respectively. Scores are plotted by site and month. Se= September 2019; Oc= October 2019; Fe= February 2020.

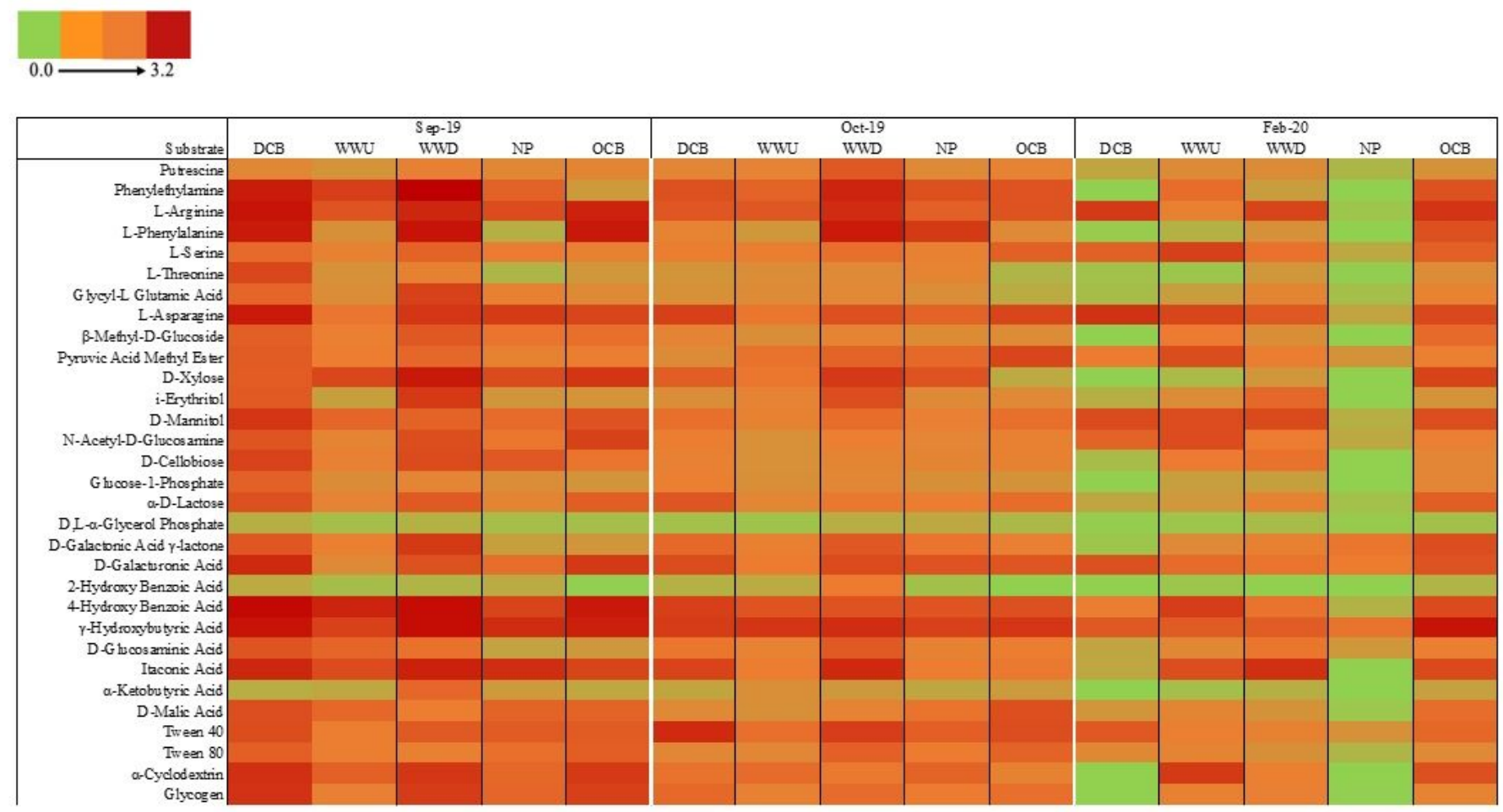

\section{Figure 5}

Heat map of carbon utilization patterns of 31 substrates from the Biolog EcoPlates based on the AWCD of $120 \mathrm{~h}$ for stream sediment microbial communities across sites in different months. The score in a heat map analysis represents the difference between the consumption of each sample for the same substrate. The highest consumption (i.e. higher AWCD) can be identified by a red color and the lowest consumption (i.e. lower AWCD) by a green color. 


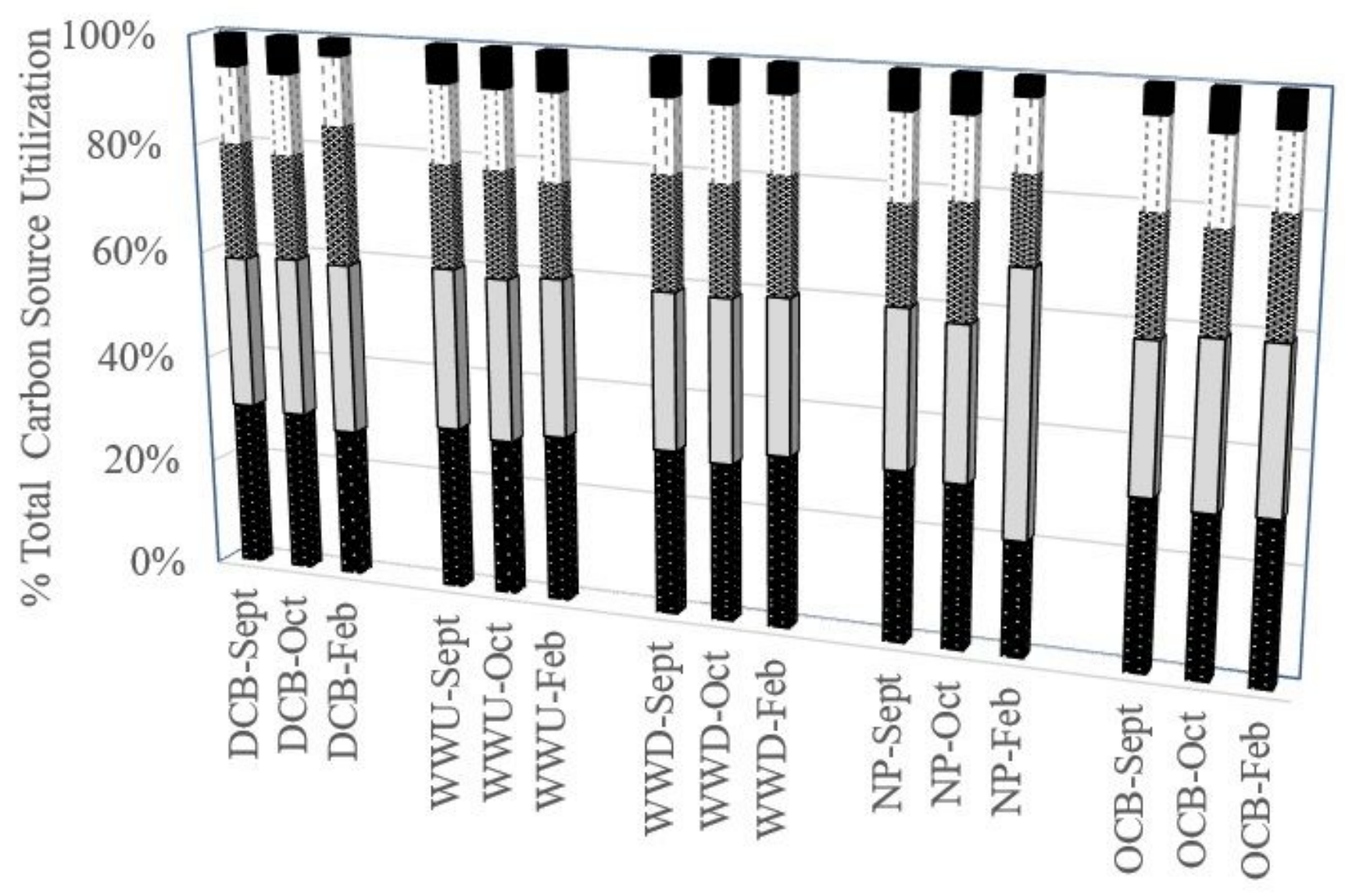

Site

- Carb $\square$ C\&AA :

\section{Figure 6}

Percent of total carbon source utilization response, per site across sampling period at 120-h OD590 for the different guilds - amines and amides (A\&A), amino acids (AA), carboxylic and acetic acids (C\&AA), carbohydrates (Carb), and polymers (Poly).

\section{Supplementary Files}

This is a list of supplementary files associated with this preprint. Click to download.

- AkinwoleetalSupplementaryMaterials.docx 